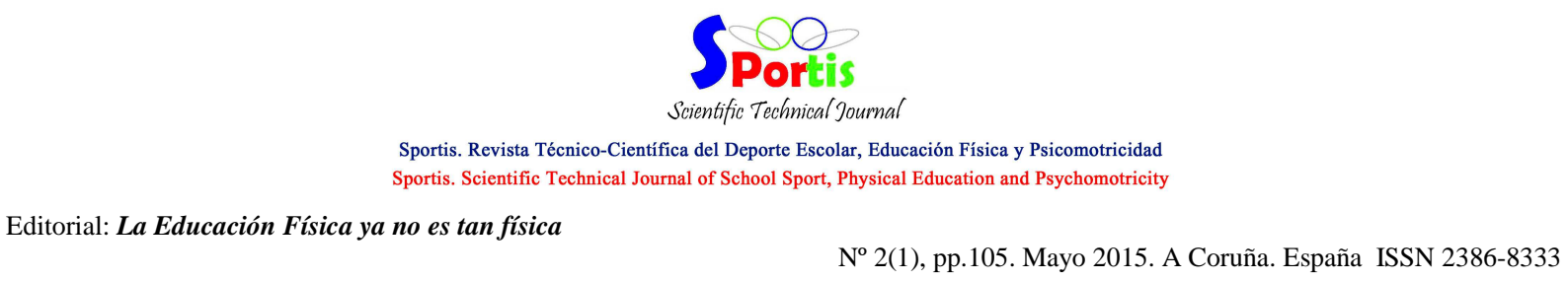

\title{
Editorial
}

\section{La Educación Física ya no es tan física}

\section{Prof. Dr. Víctor Arufe Giráldez (Universidad de A Coruña)}

Email: sportis@sportis.es

Quizá el término "Gimnasia" presente en la boca de muchos estudiantes de Educación Primaria y Secundaria no sea tan acertado como el de "Educación Física", pero este último tampoco es el que mejor define a la Educación Física actual, una educación que poco a poco se descentraliza de lo físico para basarse en lo psíquico.

Los planteamientos de muchos investigadores basados en el trabajo de valores, actitudes y normas, o las tareas propuestas para la mejora de la psicomotricidad de los niños, o el trabajo de conductas motrices dentro de una situación motriz provocando una acción motriz, constituyen los cimientos para argumentar que la Educación Física de hoy en día merece una nueva denominación. Las tareas mecánicas, analíticas y estilos de enseñanza de mando directo o reproductivos, cobran menos protagonismo frente a estilos basados en la búsqueda de soluciones o resolución de problemas, en la creatividad, en la expresión corporal, o en el descubrimiento guiado.

Es el momento de pensar un nuevo término que conduzca a una mejor aclaración de lo que se esconde detrás de esta fantástica materia. Algunas propuestas para la reflexión son: educación psicomotriz, educación para el movimiento, kinesiología, praxiología motriz, inteligencia motriz, etc.

Pero si nos centramos en uno de los principales objetivos de la Educación Física del futuro, el de promoción de hábitos de vida saludable, podemos proponer términos como, educación para la salud, ejercicio físico y calidad de vida, juegos motores y hábitos saludables, deporte y salud, salud y calidad de vida...

Les invito a pensar y reflexionar sobre este hecho, para dar cabida a un nuevo término, que se adapte a lo que es la Educación Física de hoy y lo que será la Educación Física de mañana.

Prof. Dr. Víctor Arufe Giráldez

Editor Jefe Sportis Revista Técnico Científica 